\title{
Commissioning a Visual Legacy: Louis John Steele and Sir John Logan Campbell
}

JANE DAVIDSON-LADD

In 2017, Louis John Steele's portrait of Sir John Logan Campbell at Kilbryde, c.1902, emerged on the auction market after over a century in private hands. It is a fascinating portrait of one Auckland's earliest and most celebrated Pākehā citizens. The portrait is Steele's most ambitious portrait and shows him creatively adapting the British aristocratic portrait tradition to the New Zealand context. No commissioning documents have been traced for the portrait, however a close reading of the painting alongside Campbell's papers reveal it is filled with highly personal symbolism. The provenance of the painting is also uncovered through this research. Examination of the Kilbryde portrait with Steele's five other portraits of Campbell demonstrates Campbell's desire to leave a lasting visual legacy. 
Louis John Steele (1842-1918) painted at least six, possibly seven, portraits of Sir John Logan Campbell (1817-1912).1 These paintings date from 1900 to about 1910. Only two are known to have been exhibited in his lifetime and little primary evidence about their commissioning and ownership exists. This paper focuses on Sir John Logan Campbell at Kilbryde, c.1902 (Figure 1). Until 2017, when the portrait came onto the auction market, it was known only through photographs of the artist (Figure 9). ${ }^{2}$ While no manuscript material exists about its commissioning, the Kilbryde portrait is itself a remarkable source which this paper seeks to interrogate. Examination of the painting alongside Campbell's papers decode the portrait's symbolism, giving us insights into the artist, his subject and their relationship. Seen within the broader context of Steele's other portraits of Campbell, this portrait reveals Campbell's desire to leave a visual legacy. They also demonstrate Steele's ambition for portrait painting in New Zealand.

\section{STEELE AND CAMPBELL}

Steele was born in Reigate, Surrey in 1842 . He trained in the 1860 s, initially at the Royal Academy, London, before moving to Paris and the Ecole des Beaux Arts in 1864. There he studied under Alexandre Cabanel, exhibiting at the Paris Salon 1868-70. He returned to England in late 1870 where he produced large-scale reproductive etchings after leading artists, taught and sought to exhibit. ${ }^{3}$ Scottish-painter and Royal Academician John Pettie testified that Steele was also "able to paint a good portrait." ${ }^{4}$ From the time of his arrival in New Zealand in mid-1886, he quickly made his name as a portrait painter, and subsequently history painter and teacher.

When the Kilbryde portrait was painted about 1902

Campbell was one of Auckland's earliest and longest living Pākehā residents still alive. Born in Scotland in 1817 into an aristocratic family, he trained as a doctor, before emigrating. Arriving in New Zealand in early 1840 , he made his for-

tune initially as a merchant: one half of the firm Brown and Campbell. He subsequently invested widely in land, farming, gold-mining, logging and brewing, additionally serving on the boards of key financial institutions. He made several attempts to live off his wealth in Europe, but business issues repeatedly drew him back, and in 1880 he finally decided
Auckland would be his permanent home. ${ }^{5}$ His family re-

turned to their newly built house in Parnell, named Kilbryde

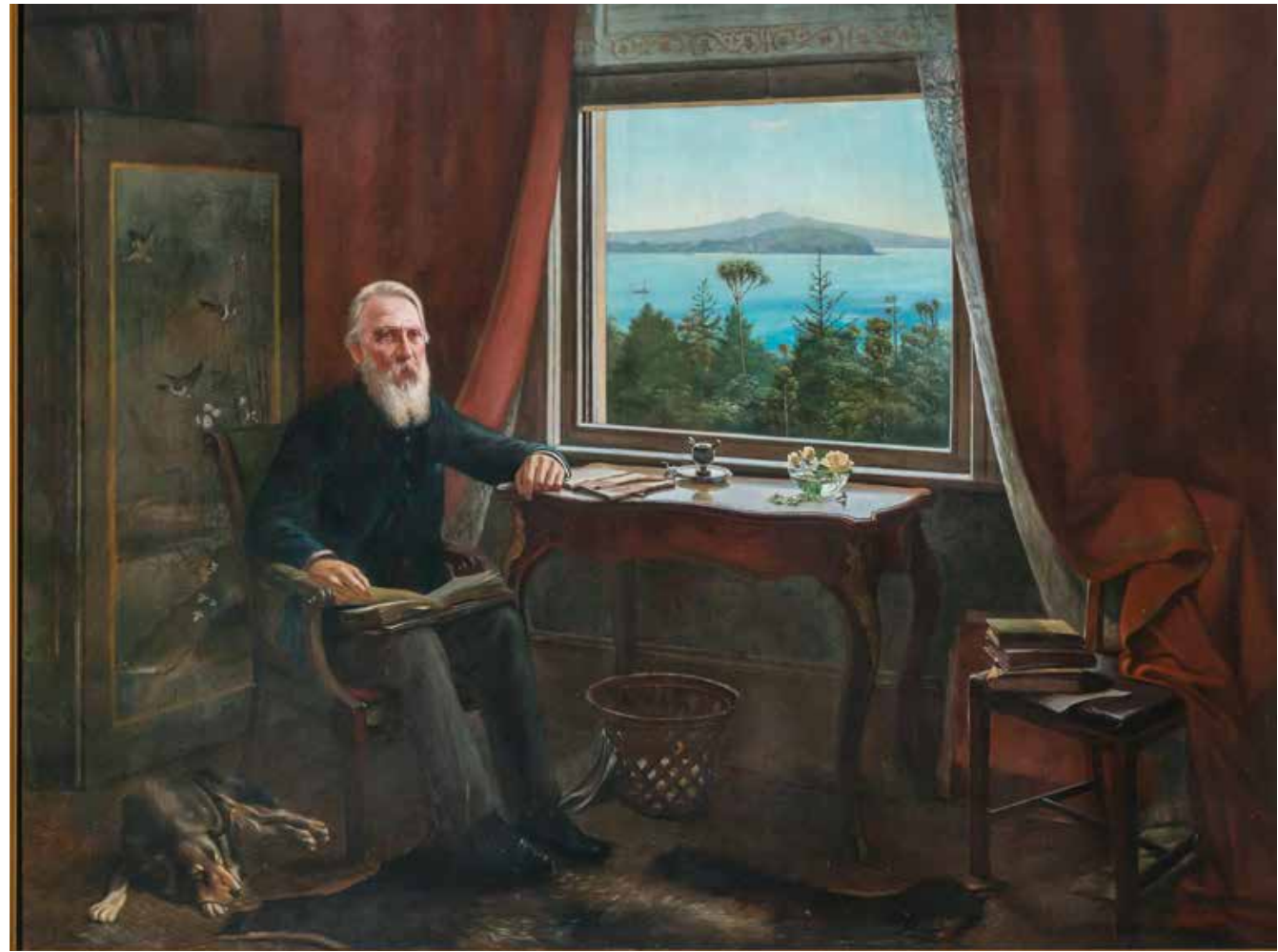

FIGURE 1. Louis John Steele, Sir John Logan Campbell Jor after his Scottish clan's castle. In 1901 he gifted his One Tree Hill estate to the citizens of New Zealand as Cornwall Park, cementing his legacy as the 'Father of Auckland.'

Steele most likely met Campbell not long after immigrating to New Zealand in 1886. Campbell was concerned by the lack of culture in New Zealand and sought to encourage the arts by funding the Free School of Art. The School was run by Kennett Watkins, with whom Steele initially collaborated, so they may well have met through him. ${ }^{6}$ Campbell had long cultivated associations with artists, and he and Steele had shared experiences: both had sampled the delights of Florence, Paris and London; and spoke French fluently. ${ }^{7}$ Steele was also one of very few highly trained artists permanently based in Auckland. Ever the canny businessman, Steele would have recognised Campbell as a potential client and benefactor and sought him out.

No correspondence has been found between Campbell and Steele. Campbell's biographer, Russell Stone, sounds a cautionary warning about the extent of Campbell's papers, commenting that "extensive though the papers are, they are also uneven and do not show us the whole man." Further 


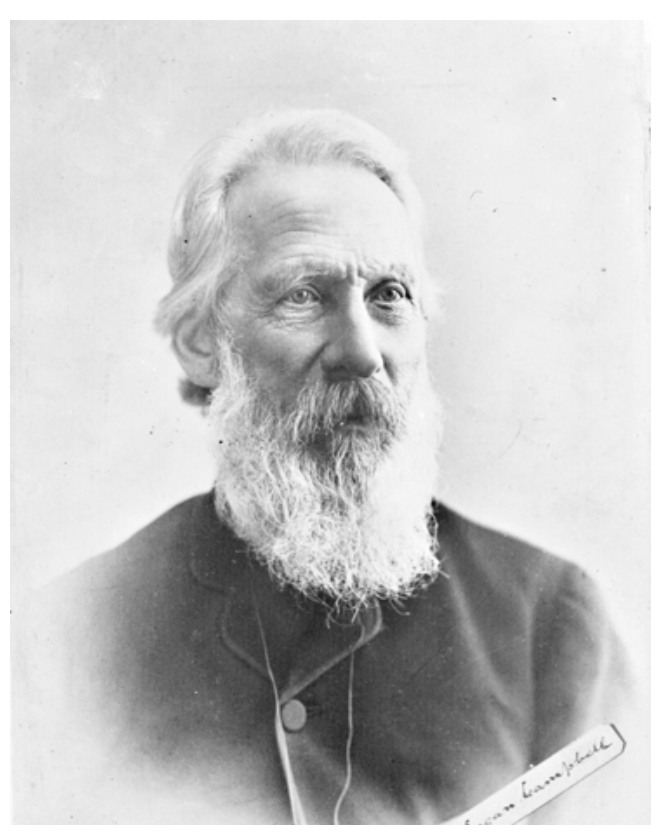

significant personal economising. ${ }^{12}$ Commissioning works of art would have been far from his mind.

The 1900 portrait received mixed praise when shown at the annual Auckland Society of Arts (ASA) exhibition. The New Zealand Herald review was complimentary, describing the likeness as "undoubtedly a successful one."13 The Auckland Star was more critical, commenting: "The position is somewhat conventional, but portrait painting of this particular class does not admit much variety or originality." Adding that "It has been said that the artist has failed to catch the suspicion of a twinkle in the eyes that is invariably present."14

The portrait does give a rather dour impression of Campbell and is indeed very conventional, but perhaps reflects the sitter's intention in commissioning it. Most likely Campbell wanted a likeness to capture him for time immemorial. There is an enduring quality to the portrait, Campbell sits at his ease his elbow resting on a document - perhaps an allusion to his coming gift of Cornwall Park in 1901.

An explanation for the missing twinkle in his eye could

FIGURE 2. Unknown photographer, Portrait of John Logan Campbell with autograph, 1900 or befor

their "preservation has been capricious and haphazard." The absence of letters may be simply enough explained by geography. Steele's studios were both on Shortland St, just paces from where Campbell had his offices, so they likely carried out their business face-to-face. ${ }^{9}$

A scrapbook belonging to Steele includes numerous photographs by Campbell of Kilbryde and its surrounds, and one of him reading..$^{10}$ Additionally there is a photographic print of a harem scene, for which Campbell appears to be the source. ${ }^{11}$ Much of the material in the scrapbook book is dated 1889 , so we can confidently date Steele and Campbell's association back this far at least.

STEELE'S FIRST PORTRAIT OF CAMPBELL, 1900

It was not until 1900 that Steele received his first commission to paint Campbell's portrait (Figure 3). Given Campbell's reputation as an arts benefactor, it is initially surprising that he waited this long to commission a portrait, especially when he went on to commission multiple portraits. The answer can be found in Campbell's dire financial circumstances through the late 1880 s and 1890s. During this time there was a great depression in the economy. Campbell survived this only through extensive borrowing, liquidating assets and shoulders photograph of Campbell (Figure 2) ${ }^{15} \mathrm{~A}$ deadening in the appearance of the sitter can occur when paintings are based on photographs: this presents most noticeably in blank eyes and unnaturally stiff posture. The stillness required for the initial photograph seemingly infiltrates the

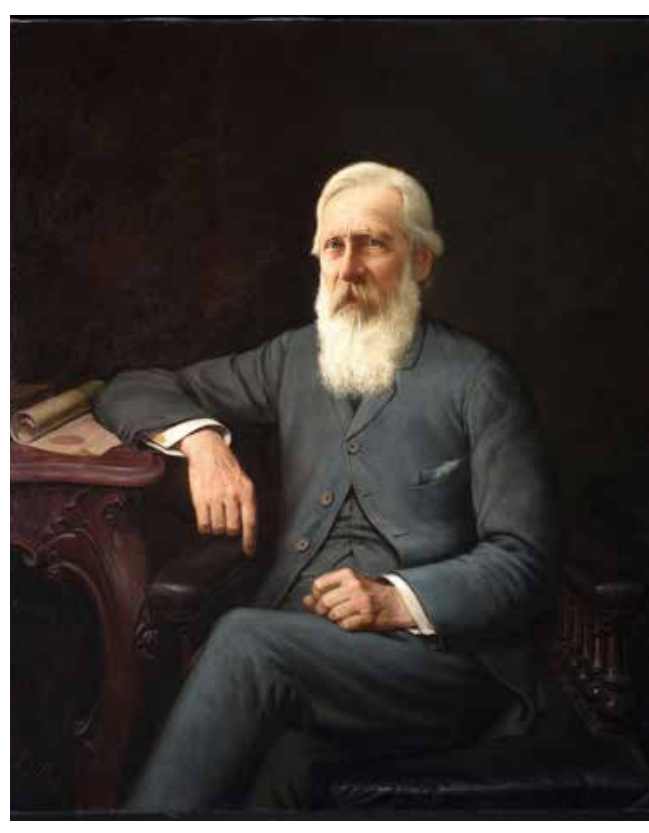

FIGURE 3. Steele, John Logan Campbell, 1900, oil on canvas, Cornwall Park Trust, on deposit Auckland War Memorial Museum, PA 
STEELE'S KILBRYDE PORTRAIT, C.1902

Steele's second portrait of Campbell is quite original within New Zealand's art history (Figure 1). As exemplified by Steele's 1900 portrait, most Pākehā portraits produced in New Zealand were half to three-quarter-length, with a plain usually dark, background. ${ }^{17}$ The Kilbryde portrait, by contrast, stands out: not only is it a full-length seated portrait, the scene is enlivened by the landscape view and elaborate interior setting. The only New Zealand portrait that comes near it in terms of ambition is William Beetham's 1857-8 portrait of Dr Featherston and the Maori chiefs Wi Tako and Te Puni which is an impressive civic group portrait. ${ }^{18}$ The intent of Steele's work is much more personal though, as I will show. Further, Beetham's interior relies on just the furniture, papers and books to evoke Featherston's study, with the background room only summarily indicated.

Steele's painting draws on the eighteenth-century British aristocratic portrait tradition which presented sitters in a quasi-outdoor setting in front of a landscape which symbolically referred to their estates or triumphs. Sir Joshua Reynolds' portrait of Sir William Hamilton, 1777, is a useful comparison..$^{19}$ The antiquarian collector and diplomat is seated in a semi-enclosed porch with a dramatic swag of rich red fabric framing the top and right sides of the painting. He is surrounded by the art treasures he collected while posted, over many years, as British envoy to Naples. He holds a volume of the lavishly illustrated series he published which documented his triumphs and discoveries as a collector.

Over his right shoulder Mt Vesuvius smokes in the distance, alluding to his passion for volcanoes on which he published extensively with the Royal Society. ${ }^{20}$

Steele adapted this format to the colonial context.

Campbell is seated by a window at Kilbryde which frames a spectacular view of his garden with the Waitemata Harbour, North Head and Rangitoto Island beyond. Gone is the ostentatious dress, and the voluminous red drapery is now literally drapes. The view depicts landmarks of the town Campbell was integral in shaping, his success modestly alluded to by

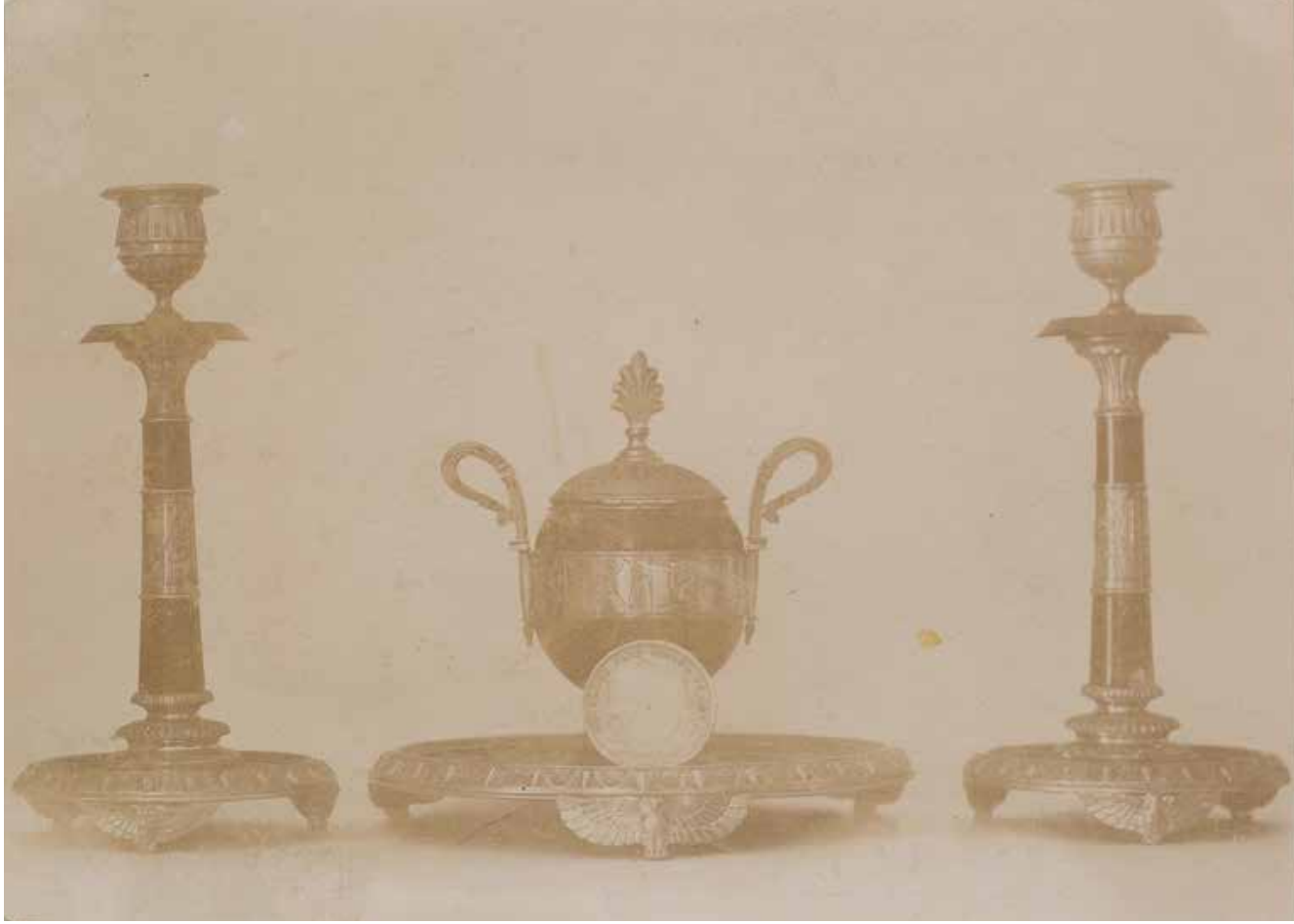

FIGURE 4. " "Presentation Free School of Art," photograph of the inkstand and candlesticks presented to ography," vol. II, p.296A. MS51-2B, Campbell Papers, Auckland Museum.

the dog at his feet. Campbell was known by this time as 'the Father of Auckland,' and the painting embodies the phrase, showing him as the town's beneficent patriarch. Yet, as the analysis below reveals, the portrait is filled with highly personal symbolism; it is much less of a civic portrait and more of a personal testament.

In the absence of commissioning documents, photographs in Campbell's papers and unpublished autobiography provide a visual key to the portrait. ${ }^{21}$ These reveal Campbell's integral involvement in the painting. This is consistent with the commissioning of the Cornwall Park statue of Campbell. Although not officially the client, he corresponded extensively with the sculptor, Henry Pegram, including sending a memo with 12 photographs of himself. ${ }^{22}$

Steele's portrait is set in Campbell's home, in either the drawing room or study on the ground floor. ${ }^{23}$ The furnishings are not studio props, rather they are found in interior photographs of Kilbryde: everything from the eccentric animal skin rug to the surprisingly fashionable oriental screen; the disordered bookcase to the opulent red curtains. ${ }^{24}$ The dog, 
too, was a part of the household, appearing in a photographic Christmas card made by Campbell. ${ }^{25}$

Placed centrally on the table is a small silver vessel with looped handles. Another photograph reveals that this is an inkstand presented by students of the Free School of Art in recognition of Campbell's role as benefactor (Figure 4). ${ }^{26}$ The inkstand was highly symbolic of what Campbell felt to be a special achievement; he personally funded Auckland's first art school from 1878 to 1889 . He wrote in the accompanying text, "Next to the Volunteer Rifle Inauguration I rank my Free School of Art as what I am most proud of having done in New Zealand." ${ }^{27}$

The prospect from the window frames Auckland landmarks, which were also redolent with personal significance. A keen amateur photographer, Campbell captured the view numerous times, including it on Christmas and birthday cards, as well as in other photographs. ${ }^{28}$ Rangitoto was particularly meaningful; he summited the volcano on multiple birthdays until well into his $80 \mathrm{~s}^{29} \mathrm{He}$ concluded his "Reminiscences" with the wish "that when my last day comes...my spirit [will] hover for a brief space above the broad waters of the Waitemata to gaze on the twin peaks of Rangitoto before it is borne away for ever!" 30

The wooded garden in the foreground was planted by Campbell. When Kilbryde was first built, the point was "bleak," "covered with tea-tree and low tough scrub." 31 Forced to let his gardeners go due to his financial circumstances in the 1880s, he slowly transformed the grounds himself. ${ }^{32}$ The improbably top-heavy tī kōuka cabbage tree, along with the young pines, appear in the numerous photographs looking just as Steele depicted them. ${ }^{33}$ Stone records that the blending of the New and the Old Worlds within the garden "held up a mirror to the dualism in Campbell's soul-his admiration for the ordered refinement of Eu-

rope, [and] his affection for the natural beauty of that colony where...he would live out his days." ${ }^{34}$

The portrait itself bears a strong resemblance to the head and shoulders photograph that was also the basis for the 1900 painting (Figure 2). Steele appears to have used the photograph as a guide rather than copying it exactly; differences can be identified in the representation of the right ear and beard for example, but much remains the same, particularly the angle of the head, the lines on Campbell's face and the fall of light. The head is somewhat awkward in relation to the body and slightly out of scale - one of the hazards of working from a photograph.

The influence of photography is also present in the composition itself. Unusually for an individual portrait, the canvas is oriented horizontally with its dimensions wider than high, recalling photographs of domestic interiors. The composition is also reminiscent of a distinctive feature of Campbell's photographic practice; he would create composite images by cutting and pasting several photographs together (Figure 5). In the illustrated example, Rangitoto appears in the background, to which he has added a balustrade and a 'cut out' of himself in a deckchair. Steele's portrait is a much more sophisticated version of the same approach, taking many elements from Campbell's life and combining them in the portrait.

Compared to Steele's other portraits, Campbell appears quite frail and small - he was in his mid-80s, so this reflected reality. ${ }^{35}$ If Steele's intention was to create a monumental impression of the Father of Auckland, Campbell's slightness in the picture, even if real, does diminish the effect. If, however, Steele's purpose was to create a more domesticated personal perspective, this fidelity to life is consistent with such an endeavour. Other aspects such as: the relative disorder of books on the empty chair, with a folio resting on the wall behind; the casually pulled curtains; the quarter-filled waste-paper basket with folded newspaper adjacent; and the awkward angle of his right foot; all give an air of informality in line with such an approach. The clutter is that of an active man, still busily employed, despite his years.

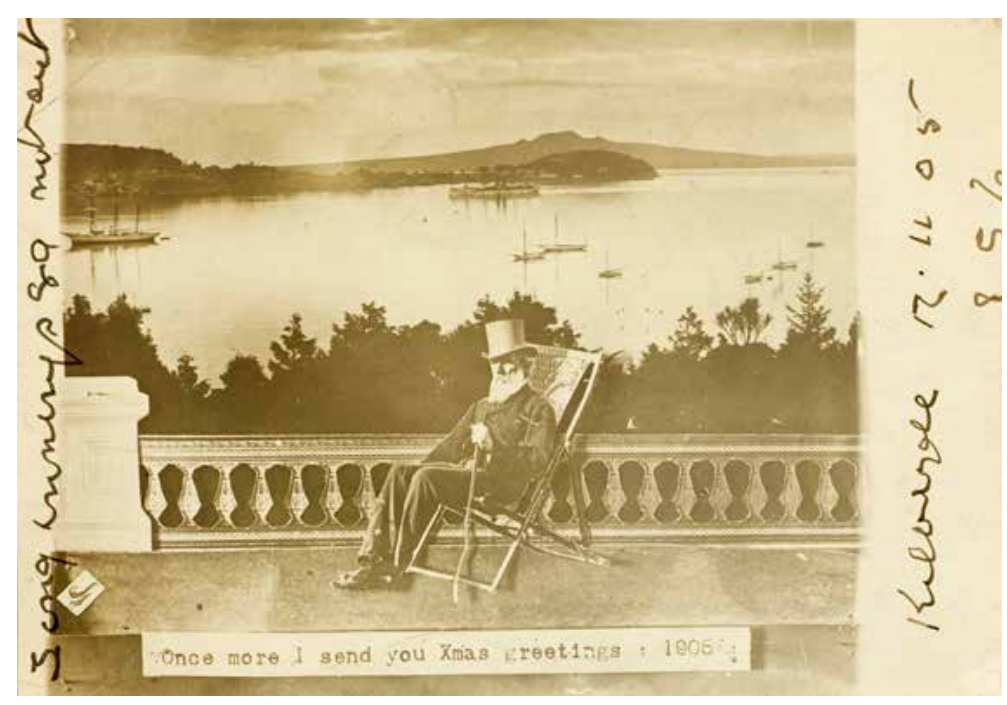

FIGURE 5. John Logan Campbell, Christmas card, 1905, photograph, Auckland Libraries Heritage Collections, 5-1125. 
On Campbell's knee a volume rests open. Stone believes this book is likely his "Reminiscences of a long life," written in $1876 .{ }^{36}$ Alternatively it could be a newspaper clippings scrapbook, which may help explain the waste-paper basket that sits under the table. ${ }^{37}$ Campbell looks up as if disturbed, the quill lying on the opened book alluding to the task he was engaged in. Since having published Poenamo in 1881, in which he narrated his early years in New Zealand, Campbell nurtured the idea of himself as a man of letters. By this means, Steele captured these literary aspirations. ${ }^{38}$

\section{STEELE'S 1910 PORTRAITS OF CAMPBELL}

The remaining four known portraits of Campbell by Steele date from 1910. ${ }^{39}$ The Auckland Art Gallery portrait was exhibited at the ASA that year, where it was offered for sale at $£ 60$ (Figure 6). ${ }^{40}$ The portrait was acquired for the Gallery by the Auckland Picture Purchase Fund. A Gallery catalogue note indicates the Cornwall Park Trust paid for its acquisition confidentially. ${ }^{41}$ The Fund's committee report singled out the painting for comment, stating how "fortunate" they felt "in being able to present a portrait of one who has done so much for the city and of who no public portrait at present exists." ${ }^{42}$

The Auckland Star review considered it an excellent likeness:

The portrait is Sir John as we have known him of late years - white haired, but hale in old age and with a countenance filled full of intellectuality, full of interest, full of countless lines telling of the experience of so many good, useful and honourable years, but filled fullest of all with kindliness, gentleness, benevolence, and humour - in fact, a speaking likeness. ${ }^{43}$

Perhaps the reviewer's personal knowledge of Campbell added something to the reading, as today Campbell's look appears stern, bordering on severe.

Steele was also complimented for the "well thought" manner in which he had arranged Campbell, resulting in a "natural, very agreeable, and yet very effective pose." ${ }^{44}$ This credit in actuality belongs to an unidentified photographer, who captured Campbell in exactly this attitude. ${ }^{45}$ Steele followed the photograph very closely, only amending contextual details such as the transformation of the carved wooden chair into an upholstered armchair and the addition of an

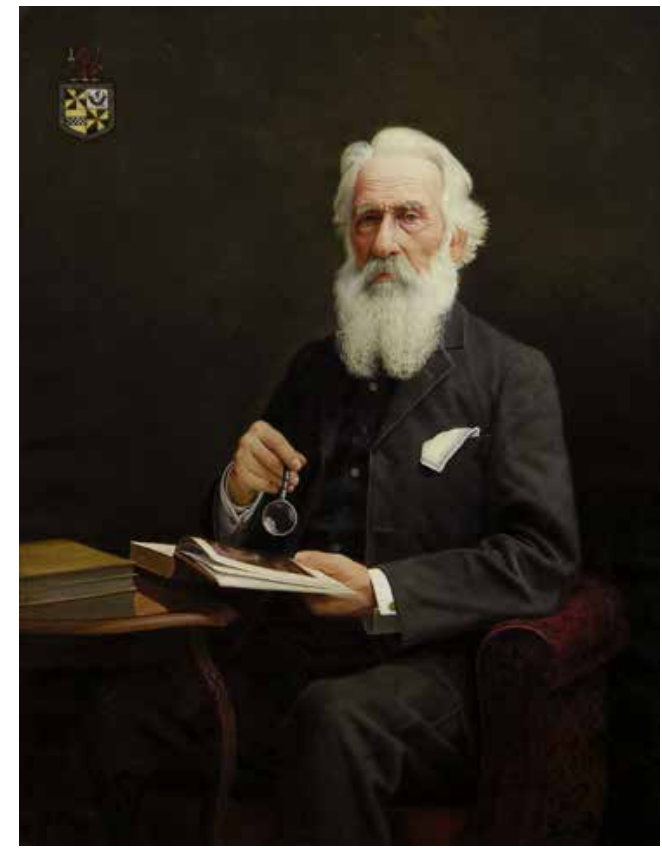

FIGURE 6. Steele, Sir John Logan Campbell, 1910, oil on canvas, Auckland Art Gallery Toi o Tāmaki, gift of the Auckland Picture Purchase Fund, 1910, 1910/2.

appearance of Campbell's face: while retaining the wrinkles, Steele smoothed away the crêpe like qualities of his aged skin and tamed the frizzy hairs of his beard.

The other three portraits from 1910 depict Campbell in the Auckland Mayoral robes (Figure 7). Contemporary newspaper reports reveal that Campbell commissioned one of these portraits to send "as a gift to the head of the Campbell family." ${ }^{46}$ This is a three-quarter length portrait with a brown background, which still hangs at Kilbryde Castle. ${ }^{47} \mathrm{~A}$ second three-quarter length version once hung in the Campbell and Ehrenfried (C\&E) offices, moving with the ownership of the firm to Lion Nathan. ${ }^{48}$ It hung alongside its pair of the company's co-founder Louis Ehrenfried, also by Steele..$^{49}$ No commissioning documents have been found, but given that it is the same format as the Kilbryde Castle portrait, they were most likely ordered by Campbell or C\&E at about the same time. ${ }^{50}$

The third Mayoral portrait, this time full-length set in a grand room, is today in Auckland Council's collection (Figure 7). The Council has no record of receiving it as a gift, nor is its presentation documented in the newspapers. Correspondence between Winifred Humphreys, Campbell's only surviving daughter, and Alfred Bankart, Campbell's close business associate solves the mystery. ${ }^{51}$ When Kilbryde was 


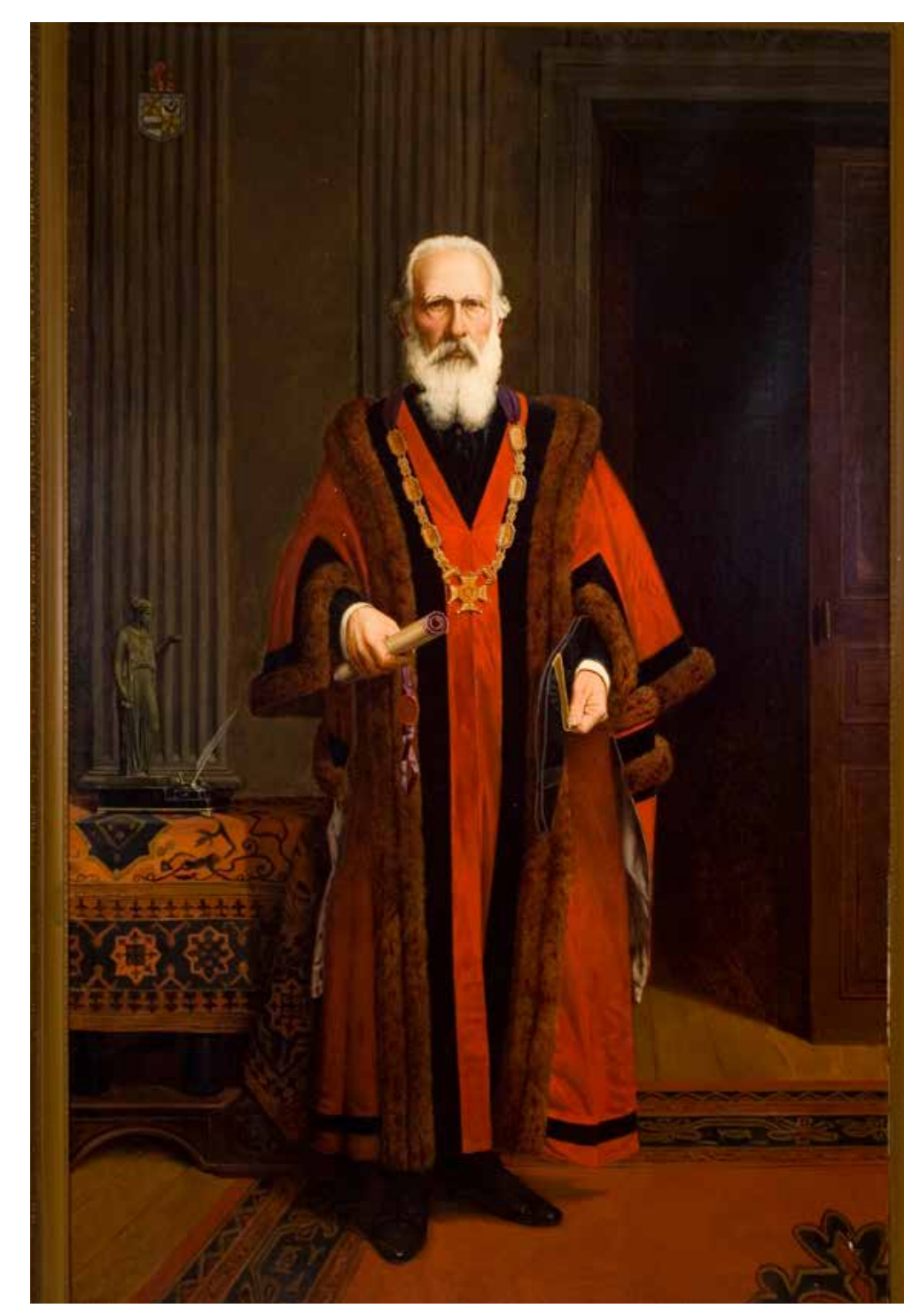

FIGURE 7. Steele, Sir John Logan Campbell, c.1910, oil on canvas, Auckland Council. One of three portraits by Steele depicting Campbell in his mayoral robes. The other two are three-quarter length with a plain background.

demolished in 1924, Bankart wrote to Winifred to describe its "passing." ${ }^{2} \mathrm{He}$ detailed a final tour with the Mayor, James Gunson. Steele's portrait was raised by Gunson:

The full-length painting of Sir John by Steele - quite a good one - which I loaned to the City Council and which is hung in the Council Chamber is desired by the Council. ${ }^{53}$ They ask me to present it to the City as a Gift so that at any time... I am very much inclined to make the Gift \& so secure to the City for all time

this very excellent portrait of one who was in

Auckland before Auckland was Auckland!

Based on this evidence, Campbell privately commissioned the portrait to hang at Kilbryde, Parnell. Following Campbell's death, Bankart loaned the portrait to the Council. He then gifted the portrait at the Council's request in $1924 .{ }^{54}$

The three Mayoral portraits are based on a 1901 photograph by the firm Hanna (Figure 8 )..$^{55}$ This was taken during the three months Campbell served as Auckland mayor while the Duke and Duchess of Cornwall and York visited New Zealand. Campbell was petitioned by Auckland's citizens to take on the mayoralty during the tour as they wanted "a fitting candidate" to welcome the Royal visitors. He accepted on the condition that he act as a "figurehead" and that he only serve a three-month term during the tour. ${ }^{56}$ Campbell had long decided to give his One Tree Hill estate to the public on his death, but this turn of events convinced him to bring forward the gift, officially presenting the park to the

Duke and Duchess and naming it in their honour. ${ }^{57}$

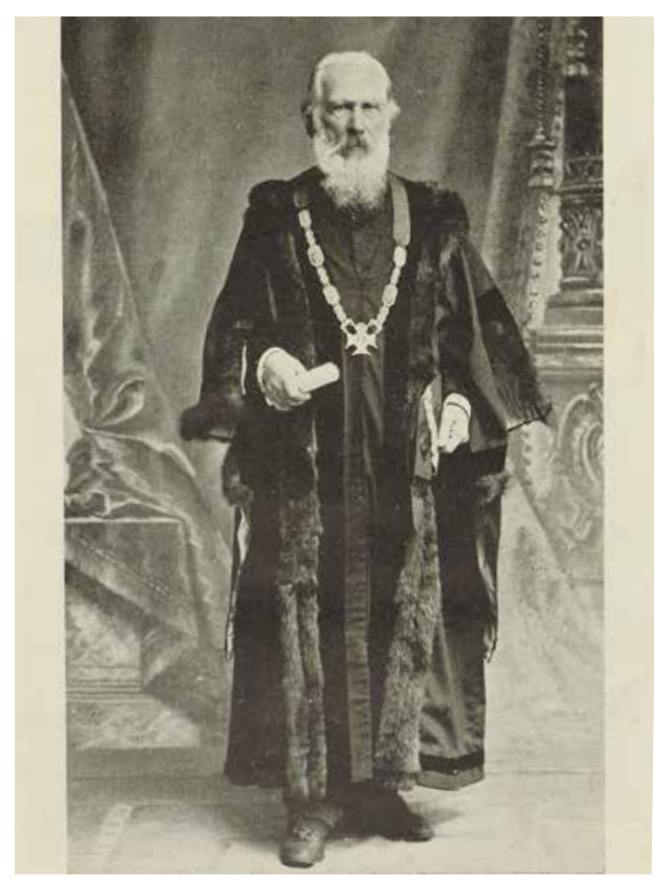

FIGURE 8. Hanna, "Dr Logan Campbell, Mayor of Auckland, in his Mayoral robes," illustration from New Zealand Graphic, 8 June 1901, 1079. Auckland Libraries Heritage Collections, NZG-19010608-1079-2. 
Steele closely follows Hanna's photograph, particularly Campbell's pose with right hand outstretched offering the deed of gift to Cornwall Park. He corrected small details, such as the uneven links of the Mayoral chain and added a ribbon and seal which hang from the document. Campbell's face is probably the aspect most changed in the paint-

ed portraits. Harshly lit from above, his head is somewhat stylised: his flat pate gives way to the rhythm of wrinkles above his brow and around his eyes, his highly groomed moustache and beard adding to the effect.

Campbell wears the newly made Auckland mayoral robes. ${ }^{58}$ The Pegram statue shows him similarly attired. It was Campbell's view that "all modern costume...kills all statuary." ${ }^{59}$ and he no doubt appreciated the gravitas the robes added to the portrait. Steele clearly relished the representation of the robes - a welcome alternative to the standard black suit his subjects usually wore - beautifully capturing the fall of the drapery, the play of light on the scarlet fabric and the contrasting textures of the silk and fur.

The background of the full-length Council version creates an illusion of three-dimensionality, not present in the three-quarter length versions with their warm brown backgrounds. The idea for the setting may have originated from the Hanna photograph, or he may have remembered another painting from his past. The portrait strongly recalls a work by Steele's Parisian master Alexandre Cabanel of Emperor Napoleon III. ${ }^{60}$ It was shown by Cabanel at the Salon in 1865 , while Steele was training under him in Paris, so he would certainly have known it. ${ }^{61}$ Steele's room is in no way as opulent as Cabanel's but, with its wooden pilasters, is nonetheless grand for the colonies. He creates a similar feeling of space, with the open door behind Campbell, along with the receding lines of the wooden floorboards and carpet, adding to this sense of depth.

Richness and texture are added to the picture through the oriental carpet and table covering. Upon the table a large inkstand is topped by a neo-classical sculpture of the goddess Hebe. ${ }^{62}$ The cupbearer to the gods, she is symbolic of eternal youth. ${ }^{63}$ Painted in Campbell's 93rd year, Hebe's appearance in the portrait no doubt alludes to Campbell long-life, but there is little else revealed of his life or personality in the painting. Overall, the portrait has a grand and imposing effect that one would expect of a civic portrait, but this is at the cost of any real sense of the man portrayed.

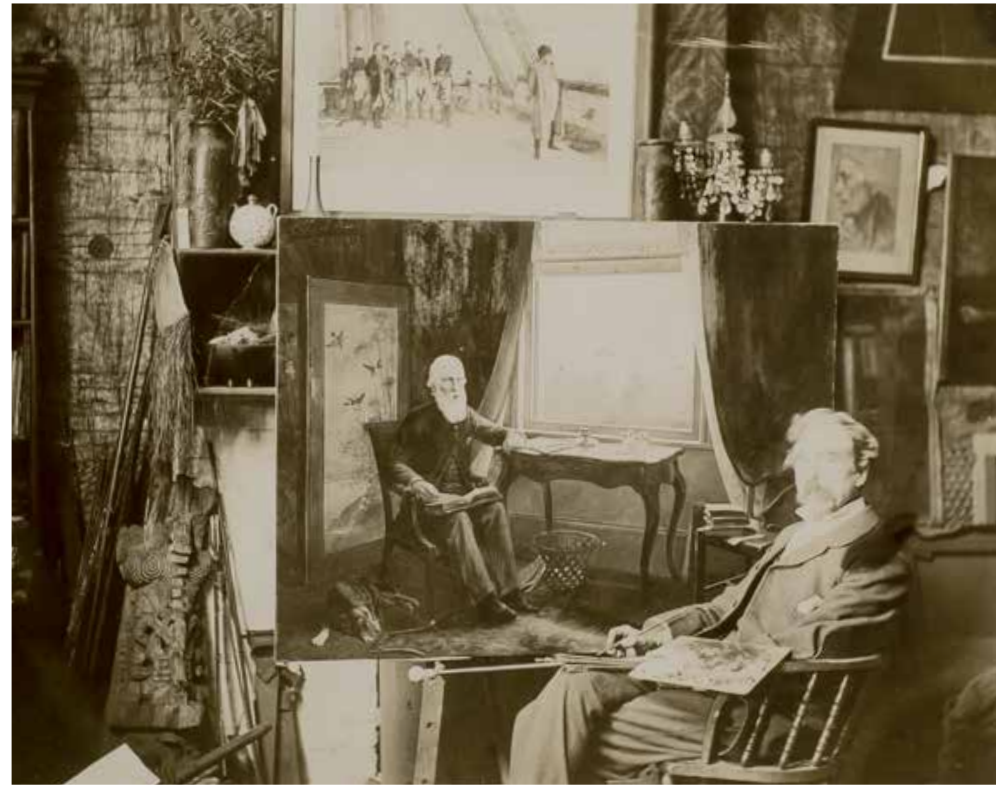

FIGURE 9. Steele pictured in his studio with the Kilbryde portrait. This photograph is an illustration in Campbell's unpublished "My autobiography: a short sketch of a lon life, 1817-1907," vol. I, p.190A, MS-51-2A, John Logan Campbell Papers, Auckland War Memorial Museum. It is a close, but not exact, match to the photograph illustrating Steele's entry in the Cyclopedia of New Zealand: Auckland Provincial District, 1902.

While the provenance of these other portraits is straightforward, mystery surrounds the whereabouts of the Kilbryde portrait from the time it was painted until it appeared at auction in 2017. While the level of personal symbolism present in the work demonstrates that Campbell must have been intimately involved in commissioning the portrait, it is hard to know with certainty what happened to the portrait after Steele painted it. Stone is of the opinion that the painting would have certainly hung at Kilbryde up until Campbell's death, but nothing that documents this survives. ${ }^{64}$

There is no evidence that the portrait was ever exhibited. Prior to its re-emergence at auction in 2017 it was known only through its reproduction in the photograph of Steele that accompanied his entry in the Cyclopedia of New Zealand, $1902 .{ }^{65}$ Entries in the Cyclopedia were paid for by those featured in the publication, using content supplied by them. ${ }^{66}$ His inclusion of the portrait in this photograph demonstrates that he clearly held the painting in high regard. It is as if Steele included it as a sampler to advertise his skills - not 
only a portrait of a prominent citizen - it also includes landscape, animal painting, still-life elements and an interior.

There is no written record of what Campbell thought of the painting, although an almost identical photograph to Steele's Cyclopedia portrait, is included in his autobiography (Figure 9), which suggests a degree of approval. ${ }^{67}$ The photograph is simply captioned: "L. J. Steele's studio." It appears in a section entirely unrelated to Steele or the portrait. While it seems natural that Campbell would want to own this photograph, no other examples of this print, or the Cyclopedia image, have been traced. ${ }^{68}$ Two identical photographs of the painting itself are amongst Campbell's papers, but there are no inscriptions that hint at their source. ${ }^{69}$ The most likely explanation is that Campbell took these photographs himself.

Clues to the fate of Steele's Kilbryde portrait are again found in correspondence between Campbell's daughter Winifred and Bankart, after Campbell's death in June 1912. Acting as executor of his will, Bankart wrote to Winifred asking what to do with Kilbryde and its contents. ${ }^{70}$ An "Inventory of Furniture \& Effects" recorded everything from candlesticks to curtain poles, but not works of art. ${ }^{71}$ There is no record of Winifred requesting pieces at this time. From subsequent letters it appears, however, that Winifred must have taken some items, including the Kilbryde portrait, when setting up 'Norholme' in 1913, the Christchurch home she briefly shared with her second husband George Humphreys. ${ }^{72}$

By 1919, she was estranged from Humphreys and had returned to Europe. Bankart wrote to discuss the removal and sale of her furniture from Norholme. ${ }^{73}$ The following year, reporting progress, Bankart recorded: “Regarding Steel[e]'s portrait of Sir John - I agree that this is a wretched pièce of work, \& I do not blame you for not having it sent to England. I don't know how I can dispose of it, but I am having it sent to Auckland." ${ }^{74}$ Unfortunately, Bankart gave no further detai to determine which painting he is referring to, however the description of it as "a wretched pièce of work" does assist

The 1900 portrait (Figure 3) owned by Cornwall Park Trust is conventional, inoffensive and competently painted; it seems highly unlikely that anyone would describe it in such strong terms. Further, the balance sheets of the Cornwall Park Trust list a portrait of Campbell amongst their assets continuously from 1914, accounting for their ownership. ${ }^{75}$

The other four known portraits are similarly conservative and unobjectionable, and their ownership is established. By contrast the Kilbryde portrait cannot be accounted for, was unique compositionally for its time in New Zealand and the depiction of Campbell as slight may have elicited such condemnation from his daughter and close associate. Bankart recorded later the same year, "I have a note of the ultimate fate of the Marbles and the Steele photo painting", but alas no further record has been found. ${ }^{76}$

The Kilbryde portrait has had a polarising effect on a number of people. It seems that neither Winifred nor Bankart liked it. The 2017 vendor reports that her mother had a similar response and would not allow the portrait to be hung in the house, which is how she came to own it. ${ }^{77}$

The previous owner wishes to remain anonymous but shared her knowledge of the painting's history from the time it entered her family's ownership at least 45 years ago. Her father worked for companies that had associations with the Strand Arcade in Queen Street. The building was built by Arthur Myers in 1899 - one of the other directors of C\&E. The Strand became the company's head office in 1914 and was also where the Cornwall Park Trust met for many years. The building remained in the ownership of the Myers family and later C\&E until the mid-1970s. ${ }^{78}$ The previous owner believes that her father must have acquired the painting through his business connections with the Strand Arcade. ${ }^{79}$

Based on this evidence it seems that Winifred rejected the Kilbryde portrait. Bankart returned the painting to Auckland, and stored it in either the C\&E offices or storage areas in or about the Strand; and over half a century later the painting was deemed surplus to requirements and sold.

One record uncovered admits a little uncertainty. In 1917 the contents of Steele's studio were sold to cover his debts. The catalogue listed lot no. 444, "Oil Painting, Sir John Logan Campbell, L J Steele". ${ }^{80}$ Could this be the Kilbryde portrait? It seems unlikely. The weight of evidence strongly supports the theory that the Kilbryde portrait was the "wretched pièce" that Winifred disliked and that Bankart stored at the C\&E premises. If this is accepted, the 1917 auction record does mean that there was a seventh portrait of Campbell by Steele which is currently untraced.

\section{CAMPBELL'S VISUAL LEGACY}

Campbell showed great pride in having descended from the Breadalbane Campbells, who were members of the Scottish aristocracy. ${ }^{81}$ All three versions of the Mayoral portrait, as well as the 1910 portrait in Auckland Art Gallery's collection (Figures 6 and 7), feature what Campbell termed "Ye Paternal Arms" in the top left-hand corner. ${ }^{82} \mathrm{His}$ grandfather was the 4th Baronet of Aberuchill and Kilbryde, but as the younger son his father had to "make his own way" in the 
world, just as in turn Campbell did. ${ }^{83}$ Campbell took great pride in what he personally achieved. In sending a version of the Mayoral portrait back to Scotland, he was asserting the extent of his triumphs in the New World to his ancestors in the Old. Stone observes that the portrait, which still hangs in Kilbryde Castle today, is "larger than any portrait of the baronets in the picture gallery, and quite dwarfing the picture of Mary Queen of Scots." ${ }^{4}$

This pride Campbell took in his heritage at times put him off-side with his New Zealand contemporaries who thought he and his wife put on airs which made him ill at ease in colonial society. ${ }^{85} \mathrm{He}$ was also ferociously defensive of his reputation throughout his career. For example, he wrote explosively from England to his New Zealand partners in late 1867 questioning why the latest Brown and Campbell ad-

vertisement individually listed every product down to calves foot jelly and red herrings. His concern was how it would reflect on him personally: "Why all the halo descending to me from my nearly three hundred years of titled ancestors could not stand against your 'calves foot jelly and red herrings'. I would be laughed out of all social position and intercourse in society with one shout of derision!"86

The commissioning of portraits is very much in line with such a view of self. Scotland had a strong aristocratic portrait tradition, which Campbell was familiar with through the ancestral portraits hanging at Kilbryde Castle. ${ }^{87}$ Through his commissioning of portraits and strategic placement of them in public and private collections in New Zealand and Scotland, Campbell was consciously tapping into this tradition, ensuring that he and his achievements would be remembered.

By contrast, Campbell could also be very self-effacing When he received his knighthood in 1902, he accepted it as "being 'conferred upon the early pioneers', rather than himself" and he preferred being called "Dr Campbell" to "Sir John." ${ }^{88}$ Another contradictory example is the response he sent to the artist Frank Connelly who offered to sculpt a statue of Campbell to stand in the recently presented Cornwall Park. After saying he did not have the money to pay for such a statue, Campbell added, " $\&$ if I had, the making of a memorial statue of myself would be something too uniquely ridiculous." ${ }^{89}$ Yet in his letter book there is a memo dated six months earlier titled, "How best to get a statue should one be wanted for Cornwall Park," in which he outlines obtaining just such a statue as that offered by Connelly. ${ }^{90}$ The fact that the Cornwall Park Trust, with whom he was closely connected, confidentially paid for the 1910 portrait in Auckland Art Gallery's collection (Figure 6), again demonstrates both
Campbell's conscious desire to leave a visual legacy and wish not to flaunt his direct involvement in this legacy making. ${ }^{91}$

There is an inconsistency and degree of false modesty in this, which is further borne out in his autobiographical writing. These personal histories clearly were intended as a lasting record of his achievements, as were the six commissioned portraits. Campbell recognised these conflicting tendencies in himself, writing in his autobiography:

And now for a confession after all this tirade of not caring a button for my Sir Johnship. Have I not often found myself saying to myself Oh! if my dear old people had only lived to see how the career of the only son who went forth from his home in 1839 to fight the battle of life ended in a knighthood would they not have been made happy. So after all I suppose human vanity prevailed and - I am only human but surely was it not a legitimate vanity. ${ }^{92}$

Given all of his achievements such pride was certainly reasonable. Steele's portraits are outward manifestations of this pride and offer a remarkable visual record of the man still very much lauded today.

Just as with his autobiographies, though, Campbell wanted to leave his version of history. Stone writes that Campbell's memoirs were "an exercise in self-assertion not self-revelation." ${ }^{93}$ This can equally be said of Steele's portraits of Campbell, with the exception of the Kilbryde portrait. The Kilbryde portrait is more self-revelatory. It melds both his public persona as the Father of Auckland along with a much more personal representation of his private self. The painting is singular in New Zealand art history for its creative adaption of the aristocratic portrait tradition to the colonial context and its innovative use of photography. It is evidence of Steele's ambition to create an artistic vernacular particular to this country and its people. 
Auckland Art Gallery. Green Catalogue Card. Louis John Steele, “Portrait of Sir John Logan Campbell," 1910/2, New

Auckland Council Archives. ACC272 Council Minutes Indexes, no. 29 (1923-4) and no. 30 (1924-5).

Auckland Council Archives. ACC108 Library Committee Minutes, 1912-1956.

Auckland Council Archives. Art work file. Louis John Steele, Sir John Logan Campbell, G001 2005.

Auckland Libraries. “Campbell, John Logan.” Photogdbtw-wpd/phoy 2021].
18 May

Auckland Society of the Arts. Catalogue of the Tweny-Ninth Annual Exhibition. Auckland: Auckland Society

Bell, Leonard. “John Logan Campbell (1817-19112): A Career in Images." Art New Zealand 67 (Winter 1993) $88-96,106$.

Bunm, Andreas, ed. Alexandre Cabanel: The Tradition of Beauty. Cologne and Munich: Wallraf-Richartz-Museum and Hirmer Verlag, 2011.

Campbell and Ehrenfried. Directors' Minute Book, 18971912. NZMS 1423 , box 3, 2/3/1, Sir George Grey Special ns, Auckland Libraries.

Campbell, John Logan. Papers. MS-51, Auckland War Memorial Museum.

Campbell, John Logan with an introduction by R. C. J. Stone, ed. Reminiscences of
David Ling Publishing, 2017.

Cyclopedia of New Zealand. "Steele, Louis John." Cyclopedia of New Zealand: Auckland Provincial District, vol. II.

Davidson-Ladd, Jane. “'The Speaking Likeness': Gottfried Lindauer's Pakehá Portralts." In Golthed Lindauer's New Zealand: The Māori Portraits, edited by Ngahiraka Maso nd Zara Stanhope, 251-62. Auckland: Auckland Art

Heritage New Zealand. "The Strand Arcade." New Zealand Heritage List. http://www.heritage.org.nz/the-list/details/123 [accessed 14 August 2018].

International Art Centre. Important and Rare Art. Auckland: International Art Centre, August 2017.

Kirby, J. W. The History of Blackheath Proprietary Schoo Blackheath: The Blackheath Press, 1933.

National Portrait Gallery. “Sir Joshua Reynolds, Sir William
Hamilton." https://www.npg.org.uk/collections/search/ portraitExtended/mw02866/ [accessed 18 May 2021].

New Zealand Electronic Text Centre. “The Cyclopedia of i-corpus-cyclopedia html\#name-412283-1 [accessed 6 July 2018]
Morson, Geoffrey V. "Hamilton, Sir William." Oxford Dictionary of National Biography. https://doi-org.ezproxy. 2021].

Parker, Robert Christopher Towneley. “Hebe.” The Oxford Antony Spawforth, eds., online edition, 2005.

Richard Arthur \& Co. Catalogue of Sale: The Whole of the Valuable Collection Pictures Works of Art Maori \& Island Curios etc. The Property of L. J. Steele, Esq. Artist. Auckland: Richard Arthur \& Co., 1917.

Steele, Louis John. Scrapbook. Private collection, Whanganui.

Stone, R. C. J. “John Logan Campbell, Frank Connelly and "Jesprano. Literary Evidence in Blography." New Zealand Journal of History, no. 1 (1976): 21-36.

Stone, R. C. J “ “A Victorian Friendship and Auckland's $\mathrm{htm}$.

Stone, R. C. J. The Father and his Gift: John Logan Campbell's Later Years. Auckland: Auckland University Press, 1987.

Stone. R. C. J. “Campbell, John Logan.” Dictionary of Ne Zealand Biography, 1st pub. 1990. Te Ara - the Encyclopedias essed 20 May 2021 Stone, R. C. J. ed. Poenamo Revisited: A Facsimile of the 1898 Edition of Poenamo by Sir John Logan Campbell. Auckland: Godwit, 2012. I would like to acknowledge the assistance and encour-
agement of Russell Stone in writing this paper, along with my father Allan Davidson.

1. For a summary of other portraits of Campbell from throughout his life, see Leonard Bell, “John Logan Camp(Winter 1993): 88-96, 106.

2. "Lot 38, Sir John Logan Campbell at Kilbryde, Parnell" in International Art Centre, Important and Rare Art

3. Steele claimed to have remained in Paris during the siege of 1870-71, but evidence suggests he returned to London taking up a position as Head Drawing Master at Blackheath Proprietary School in October 1870. J. W. Kirby, The History of Blackheath Proprietary School W.

4. Testimonial letter, John Pettie to Louis John Steele, 3 186, published in the Observer, 5 Oct 1889, 18.

5. R. C. J. Stone, The Father and his Gift: John Logan Campbell's Later Years (Auckland: Auckland University

6. R. C. J. Stone, "A Victorian Friendship and Auckland's First School of Art," Art New Zealand 30 (Autumn 1984, https://www.art-newzealand.com/Issues21to30/1soa.

7. Stone, The Father and his Gift, 144, 171

8. R. C. J. Stone, "John Logan Campbell, Frank Connelly and 'Trespiano': Literary Evidence in Biography," New Zealand Journal of History, no. 1 (1976): 21

9. Steele had a studio in the Victoria Arcade from his arrival in 1886 until about 1904 , when he is then listed the Hobson Bulldings. NZ City \& Area Directories, 1866 1955, www.ancestory.com [accessed 6 May 2014]. Sto Auckland when writing in an official capacity such as following up a debt, or if they were out of town. Russell Stone, conversation with author, 31 July 2018.

10. Eight pages of the scrapbook include materi relating to Campbell. There are three full page images of Kilbryde, the other pages include three to five photomonogram Louis John Steelos tion, Whanganui.

11. Multiple copies of this print, along with similar examples, are found in Campbell's papers; presumably made papers. Auckland War Memorial Museum (CP. AWMM). 12. Stone, The Father and his Gift, see "11: Falling into Debit," 170-181 and "13: Against the Tide," 204-223.

13. "Auckland Society of Arts Exhibition," New Zealand Herald (NZH), 18 October 1900, 6.

14. "Auckland Society of Arts," Auckland Star (AS), 22 October 1900, 2.

15. MS-51-323A-13, CP, AWMM and Auckland Librarie Heritage Collections, 4-1364.
16. Jane Davidson-Ladd, "'The Speaking Likeness': Gottfried Lindauer's Pākehā Portraits," in Gottfried Lindauer's New Zealand. The Maoori Portraits, eds. Ngahiraka Mason Tâmaki, 2016). 261.

17. Ibid. A similar formula was used for most Mãor portraits, although from about 1889 Steele set his Māor portraits in a whare. Lindauer occasionally suggested generally used a brown background.

18. William Beetham, Dr Featherston and the Maor chiefs Wi Tako and Te Puni, 1857-8, oil on canvas, Te Papa Mealand, acquired 1881, 1921 0001-1.

19. Sir Joshua Reynolds, Sir William Hamilton, 1777, oil on canvas, National Portrait Gallery, London, NPG 680.

20. "Sir William Hamilton," https://www.npg.org.uk/ collections/search/portraitExtended/mw02866/ [acWilliam" May 2021]. Geoffrey V. Morson, "Hamilton, Sir doi-orgezproxyacklandac $\mathrm{nz} / 101093 / \mathrm{ref} / \mathrm{odnb} / 12142$ [accessed 18 May 2021]

21. John Logan Campbell, "My Autobiography: A Shor Sketch of a Long Life, 1817-1907," vol. I and II, MS-51-2A and $\mathrm{B}, \mathrm{CP}, \mathrm{AWMM}$. Campbell's "Reminiscences" and "My with an introduction by R. C. J.Stone ed Reminiscences of a Long Life (Mangawhai: David Ling Publishing 2017).

22. Campbell, "Memo Re. Pegram," 1 July 1904, MS-5 287-5, CP, AWMM.

23. The arrangement of the rooms of Kilbryde are described in Stone, The Father and his Gift, 170. The relatively low angle of the view out to the harbour suggests the room in which he is seated was on the ground floor. A photograph of Campbell's study includes the animal skin rug upon which his feet rest, and a bookcase similar to to be in the him. However, he study window appears ing would not pe posib Also the high skiting pard ing would not be possible. Also, the high skirting board the photograph of the study but are seen in other rooms. Stone, The Father and his Gift, illustration ff. 97.

24. The screen appears in a photograph of a bedroom in Campbell, “My Autobiography," vol. I, cxix, MS-51-2A, CP, AWMM; the curtains in a fill-length photographic portrat AWMM.

25. "My Autobiography," vol. II, 349A, MS-51-2B, CP, AWMM.

26. Ibid, 296A

27. Ibid, 340 .

28. Campbell's interest in photography is not well documented. He was a founding member of the Auckland Camera Club, established in 1885, and is associated with its later incarnations. "Campbell, John Logan," Photographers Database, Auckland Libraries, http:// www.aucklandcity.govt.nz/dbtw-wpd/photographers/ 
basic_search.htm [accessed 18 May 2021]. Campbell had a dark room at Kilbryde and numerous photographs in his papers are attributable to him. He frequently included a monogram featuring his initials in pictures of Kilbryde and
its surrounds. For the dark room, see "Kilbryde Inventory of Furniture and Effects," 1912, MS-51-10; for photograph by Campbell see MS-51-323 through MS-51-325, CP, AWMM.

29. Campbell with an introduction by Stone, Reminiscences, 302.

30. Ibid, 251. I am grateful to Russell Stone for pointing out this passage and the significance of Rangitoto to

Campbell.

31. "The Man Whom Auckland Honours... An Interesting Biographical Sketch," NZH, 24 May 1906, 7

32. Stone, The Father and his Gift, 171

33. For photographs of Kilbryde garden see MS-51-324D and E. CP. AWMM

34. Stone, The Father and his Gift, 171

35. Campbell recorded in 1904 that his height was only ve feet eight inches. Campbell, "Memo Re. Pegram,"

36. Stone, conversation with the author, 2 August 2017. An illustration of Campbell's original bound manuscrip is in Campbell with an introduction by Stone, Reminiscences, 9

37. Including a rubbish bin in a painting is highly unusual; it may be a nod to Campbell's habit of scrapbooking clippings, the unused newspaper ending up in it.

38. He referred to himself as possessing "a literary turn of mind." Stone, The Father and his Gift, 230.

39. Another apparent Steele portrait is in fact a replica of the C\&E portrait mentioned below. It was painted by Michael Young in 1983 and presented to the Northern Club by Sir Kenneth Myers. It is attributed to Steele in $\mathrm{R}$ 1898 Edition of Poenamo by Sir John Logan Campbell (Auckland: Godwit, 2012), 265.

40. Auckland Society of the Arts, Catalogue of the Twenty-Ninth Annual Exhibition (Auckland: Auckland Society of Arts, 1910), 11

41. "Confidential) Presented by the Auckland Picture Purchase Fund, 1910 - CORNWALL TRUST)." Louis John Steele, Portrait of Sir John Logan Campbell, 1910/2, Green Catalogue Card, New Zealand collection, Aucklan Art Gallery, undated. These cards predate the Gallery's collection databases and were created and subsequen added to by staff as part of the documentation of the sions register.

42. "Art for the City," AS, 29 July 1910, 6.

43. "Auckland Society of Arts," AS, 28 May 1910, 8.

44. Ibid.

45. MS-51-323C-17, CP, AWMM.

46. "Local and General News," NZH, 30 July 1910, 6.
47. Sir James Campbell, 9th Baronet of Aberuchill and to author, 12 June 2018.

8. These portraits are now in an associated private collection.

9. Louis Ehrenfried died in April 1897. His nephew Arthur Myers took over his share of the firm.

50. The C\&E Minute books do not have any references the commissioning of these portraits. The portrait of Louis Ehrenfried is assumed to have been commissioned died in 1897. The Campbell portrait must post-date the June 1901 photograph upon which it is based. Campbel and Ehrenfried, Directors Winute Book, 1897-1912. NZMS 423, box 3, 2/3/1, Sir George Grey Special Collections, Auckland Libraries.

1. Bankart was company secretary at C\&E, a member of the Cornwall Park Trust, one of the executors of Campbell's will and also managed Winifred's affairs in New Zealand.

52. Alfred Bankart to Winifred Humphreys, letter, 31 July 24, MS-51-335, CP, AWMM.

53. The full-length portrait cannot have been the portrait listed amongst the Cornwall Park Trust's assets, as that work continued to be listed amongst its assets beyond See “Cornwall Park Trust," AS, 15 May 1926, 12.

54. The lack of records suggests this was a gentleman's greement. No references to the gift of the portrait were found in the following: ACC272 Council Minutes Indexes, no. 29 (1923-4) and no. 30 (1924-5); and ACC108 Library Archives. Therutes books that survive from this period. Nor is there any information in the art work file, Louis John Steele, Sir John ogan Campbell, G001 2005 214 1, Auckland Council Archives.

55. J. R. Hanna, "Dr Logan Campbell, Mayor of Auckland in his Mayoral robes," NZ Graphic, 8 June 1901, 1079

56. Stone, The Father and his Gift, 238-9.

57. Ibid, 240 .

58. Ibid, 239

59. Campbell to Austin Strong, letter, 13 August 1904, MS-51-272-8, CP, AWMM.

6. Alexandre Cabanel, Emperor Napoleon III, 1865, oil on canvas, Musée National du Château, Compiègne, France. 61. Andreas Blühm, ed., Alexandre Cabanel: The Tradition of Beauty (Cologne and Munich: Wallraf-Richartz-Museum and Hirmer Verlag, 2011), 115.

62. The inkstand has not been traced, but Hebe is based on Bertel Thorvaldsen's 1816 statue of the goddess. See seum, https://thorvaldsensmuseum.dk/en/collections/ work/A874 [accessed 10 July 2018].

63. Robert Christopher Towneley Parker, “Hebe," The
Oxford Classical Dictionary (3 rev. ed.), eds., Simon Hornblower and Antony Spawforth, online edition, 2005.

64. Stone, interview with the author, 31 July 2018

65. "Steele, Louis John," Cyclopedia of New Zealand: Auckland Provincial District, vol. II (Christchurch: Cyclopedia Company, 1902), 32

66. New Zealand Electronic Text Centre, "The Cyclopedia of New Zealand," http://nzetc.victoria ac.nz/tm/scholarly/ tei-corpus-cyclopedia html\#name-412283-1 [accessed 6 July 2018].

67. Campbell, “My Autobiography," vol.I, 190A, MS-51-2A,

68. Steele may have been the source or, given his interest in photography, Campbell could have been the photographer.

69. MS-51-323C-6 and MS-51-323C-6 duplicate, CP.

70. Bankart to Winifred Murray (Humphreys from 1913), telegram, 15 August 1912, MS-51-334, CP, AWMM

71. "Inventory of Furniture and Effects in and about the nell," 27 June 1912, typescript, MS51-10, CP, AWMM.

72. Winifred's first marriage to Herbert Murray ended in 1900 , she remarried George $\mathrm{H}$

73. Bankart to Humphreys, letter, 21 July 1919, MS-51335, CP. AWMM.

74. Bankart to Humphreys, letter, 1 March 1920, MS51-335, CP, AWMM. The contents of Norholme was sold in April 1920. Christchurch Press, 9 April 1920, 10. Oil paintings were included in this, but none were individually listed as might be expected of a portalt or a well-known figure, further Bankart's letter records his intention to take

75. These were published periodically, including: NZH, 3 July 1914, 4; AS, 15 June 1915, 12; NZH, 1 May 1920, 12; and AS, 15 May 1926, 12.

76. Bankart to Humphreys, letter, 24 August 1920, MS51-335, CP, AWMM.

77. Anonymous vendor, conversation with author, 31 July 2018. She explained that she first encountered the father wished to have the pinting in the hou a clother mother did not like it.

78. "Strand Arcade," New Zealand Heritage List, http:// www.hortage.org.nz/the-list/details $/ 23$ [accessed 14 August 2018].

79. This closely accords with the provenance of a C\&E branded mirror in AWMM's collection. According to the catalogue, "Everything that came out of the pubs was put into storage beneath their NZ Wines \& Spirits store in Wellesley St." Lady Margaret Myers, who undertook the interior decorating of the hotels, invited the donor to ac-
company her to the store "where Lady Myers asked her if there was anything there she would like as it wasn't being used. Campbell \& Ehrenfried Co. Ltd, Mirror Advertising Sign, 2015.92.1, AWMM, http://www.aucklandmuseum. com/collections-research/collections/record/am_hu-

80. Catalogue of Sale: The Whole of the Valuable Collection Pictures Works of Art Maori \& Island Curios etc. The Property of L.J. Steele, Esq. Artist (Auckland: Richard Co., 1917),

81 Stone, The Father and his Gift, 28, 68, 177, 228, 242

82. Campbell, “My Autobiography," vol. I, 8A, MS-51-2A, CP, AWMM.

83. R. C. J. Stone, “Campbell, John Logan," Dictionary of New Zealand Biography, 1st pub. 1990. Te Ara - the Zia of New Zealand, https://teara.govt.nz/en/ 2021].

84. Stone, The Father and his Gift, 259

85. Ibid, 227.

86. Campbell to James Mackelvie and Andrew Wardrop, letter, 31 October 1867 reproduced in ibid, 66.

87. Further, a portrait of Campbell was commissioned by his family before he emigrated. Mungo Burton, Dr John Logan Campbell, 1838, oil on canvas, Paul Mellon Collection, Yale Centre for Britsh Ant, BT 974.3.2. See Bell, “Jo (1) Campbell" Art New Zealand, 88 and 91-2.

88. Stone, The Father and his Gift, 242. "My Autobiography," vol. II, 402, MS-51-2B, CP, AWMM.

89. Campbell to Connolly, letter, 14 March 1902, quoted in Stone, The Father and his Gift, 247. Campbell's empha-

90. John Logan Campbell, “Memo," 2/22[?] October 190 Letter book, 1881-1904, 419 verso, MS-51-128, CP, AWMM. As we have sedity 91. Campbell attended meetings of the Cornwall Park Place Manager, Corrwall Park, email to author, 20 May 2021. The Trust Board members included his business partner Arthur Myers and close associate Alfred Bankart.

92. "My Autobiography," vol. II, 403, MS-51-2B, CP,

93. Stone, The Father and his Gift, 135 